\title{
The Use of Read, Cover, Remember, Retell (Rcrr) Strategy in Improving Students' Reading Comprehension Ability
}

\author{
Marlin Steffi Marpaung \& Risnawaty Sinaga \\ Corresponding author Marlin (marlin.marpaung@unai.edu) \\ Universitas Advent Indonesia
}

\begin{abstract}
Reading is one of the important skills in English needed by the second language learner. The purpose of this study is to find out is there a significant difference on students' reading comprehension through Read, Cover, Remember and Retell (RCRR) strategy. The population were VII grade students of SMPN 10 Cimahi. They were divided into two groups, the experimental and conventional group. The experimental group was taught using RCRR strategy while the conventional group was taught using conventional method. This study used quantitative research method and experimental design by using pre-test and post-test. The study was designed to find out the answer of the following questions: Are the students have same level of ability before the treatment? Is there a significant difference on students' achievement in reading comprehension between the experimental and conventional group? What is the students' response toward Read, Cover, Remember and Retell (RCRR) strategy?. The instrument used for this study is reading comprehension test and a questionnaire. The result of this study showed that there was a significant difference on students' achievement in reading comprehension with mean score of pre-test was 40.27 and mean score of post-test was 73.47. The result of the questionnaire toward the students' responses was $68 \%$ positive. It indicated that students had a positive response toward the RCRR strategy. Furthermore, the suggestion for the English teachers, it is recommended to use RCRR strategy to teach reading comprehension in their classes because it can improve the students' reading comprehension ability.
\end{abstract}

Keywords: RCRR (Read, Cover, Remember, and Retell), Conventional, Reading Comprehension

\section{Introduction}

As an international language English plays an important role and must be understood by everyone in this world. In Indonesia English is not their first language, therefore, they have difficulty in learning English. "Indonesian students often experience problems when learning English because English differs from Bahasa Indonesia (the Indonesian language) in its structure, pronunciation, and vocabulary" (Katemba, 2019). Further Morrisson (2014) stated that "English is a difficult subject because it is not the first or second language for them". So English is a difficult lesson to be understood by them. English language has four skills; listening, speaking, reading and writing and also English has a vast vocabulary, though counting how many words of any language is impossible. In dealing with today's modern 
era, students are required to read a lot and be able to understand English texts so that they are not left behind in the development of science and they are required to achieve academic and social success (Lacina, Bauml, \& Taylor, 2016).

Reading is very important for the students in schools, from elementary level to senior high school or vocational high school level. As it is stated in Permendiknas no. 23 Year 2006, the aim of reading in the curriculum is to make the students are able to comprehend the meaning of written language, both interpersonal and transactional. Reading is language, and language is made up of words. Words reflect experiences according to Gerald (2009). Reading can also be defined as the process in which readers learn something from what they read and involve it in the academic context as a part of education (Grabe, 2009). As reading is included in learning, the readers try to grasp the texts being read by interpreting, synthesizing, evaluating, and selecting the important information. Three basic definitions of reading have driven literacy programs in the United States (Foertsctr, 1998). The first definition is learning to read means learning to pronounce words, second is learning to read means learning to identify words and get their meaning, and third definition is learning to read means learning to bring meaning to a text in order to get meaning from it. Klingner and Vaughn (2007) stated that vocabulary mastery also affects reading comprehension. It is impossible to understand the text if the reader does not know much about a large number of words in the text. By mastering many vocabularies, readers can construct the meaning of text easily, so the readers must have the ability to understand English to overcome problems faced by them. Karimi \& Veisi (2016) argued that reading resilience can overcome the serious problems of a large number of students (EFL) in reading, understanding, and translating texts.

\section{Background of the study}

The fact that there are many students in Indonesia still have low ability in reading comprehension. A study was conducted by Central Connecticut State University, Indonesia ranks 60th out of 61 countries in terms of reading interest (Jakarta Post, 2016). Another fact that proves the reading ability of senior high school is low proved by the research done by the Programme for International Student Assessment (Jakarta Post, 2013). They conducted a reading literacy survey in senior high school with students' age between 15 - 16 years, they found out that Indonesia is ranked 62 out of 70 participating countries. Most of Indonesian students do not understand the definition, the generic structures and the language feature in a narrative text. This reality was stated by Aruan and Sinur (2012) on their research based on initial observations they have made, the low ability of students to read is because they are less able to understand the text. So they unable to answer questions related to the text. These realities of students' reading ability showed that the students' ability of senior high school in reading comprehension was still low.

The problems of students in reading can be solved through the application of various types of reading strategies. The problems can be solved through the learning process by the teacher, one of them by using appropriate teaching strategies. There are many teaching reading strategies for students who are active in doing comprehension activities and it needs an appropriate strategy to help them solve the problems. One of them is Read, Cover, Remember, Retell (RCRR) strategy. According to Brummer and Macceca (2008) that Read, Cover, Remember, Retell strategy is an effective approach to help readers who are good in reading is reading quickly and as a result, they do not understand what they have read. It is modeled for students during a whole-class instruction period and then is conducted with students who work as partners to read the same text. The students have an opportunity for giving mutual support and stimulation and students are also motivated to share their information or express their each other stories. It means reading with this strategy will be able to read quickly followed by good 
results from the understanding of what they have read. Then, reading comprehension by using this strategy is believed to improve students' reading abilities.Yulimariza (2013) stated that Read, Cover, Remember, Retell strategy can increase students' motivation in learning English, especially reading and it can make them think more active and critical in understanding the text. Anita (2013) concluded that strategy can also improve students reading comprehension. It is known that using Read, Cover, Remember, Retell strategy in improving students' reading comprehension ability will give good effects to the students.

Statement of the problem

Based on the background above, the problems were formulated as follow:

1. To find out the initial ability of the students before the RCRR treatment?

2. Is there any significant difference on students' achievement in reading comprehension between the experimental and conventional group?

3. What is the students' response toward Read, Cover, Remember and Retell (RCRR)?

Aims of the Study

The purpose of this study was to investigate whether the RCRR strategy (Read, Cover, Remember, Retell) improve student achievement in reading comprehension and to find out students' achievement in reading comprehension through the application of Read, Cover, Remember, Retell (RCRR) strategy.

Hypothesis

Based on the problems above, the researcher provided the hypothesis as follow: $\mathrm{H}_{\mathrm{o}}$ : Null Hypothesis.

There is no significant difference between students' reading comprehension between the experimental and conventional group.

$\mathrm{H}_{\mathrm{a}}$ : Alternative Hypothesis

There is a significant difference between students' reading comprehension between the experimental and conventional group.

\section{Related Literature \& Studies}

Reading comprehension is the activity of reading in which the readers build comprehension of a text. Reading comprehension combined logical thinking that is owned by a collection of letters, words, and sentences that are in the text. This is in line with the statement of Snow (2002) which stated that reading comprehension is the process of simultaneously extracting and constructing meaning through interaction and involvement with written language.

According to Shanahan (2006), "Reading comprehension is the act of understanding and interpreting the information within the text". Scott and Steven (2005) also said that reading comprehension is the ability to identify meaningful relations between the various parts of a text and between these parts and the readers' background knowledge. Reading comprehension has become as the problem faced by the students were arise since the teacher never gave a clear explanation toward how to comprehend and understand the text.

Sam and Premalatha (2013) notified that, "There are various functions of graphic organizers. In reading comprehension, they assist learners to clarify and organize information into categories (the main idea, supporting details, topic sentence, facts, opinion, etc.), organize information in a paragraph for better understanding, construct meaning of difficult words and sentence dividing into lexis, understand the context by associating with prior knowledge, and identify conceptual and perceptual errors that may occur in the course of reading a passage". 
Spears (2013) said that skill is the important thing in reading comprehension because the reader can use it to prior knowledge, make connections, visualize, infer, ask questions, determine importance, and synthesize the materials that they read.

Teaching reading comprehension is essential because reading is the most important activity in any language class. Teaching is an activity in which the teacher guides and facilitates learning, gives a chance for the learners to learn, and sets the condition for learning (Brown, 2001). The teacher can help the students in gaining knowledge by giving facilities such as tasks. By giving these tasks, the teacher lets the students study by themselves.

Based on Brown's teaching reading comprehension definition, teaching reading comprehension was the guidance that is done by the teacher to make learners reach their reading comprehension of the text using a certain technique. The teacher can lead the learners to understand a text by using some strategies on reading comprehension (Pang, et.al. 2003). Teaching reading is a part of the activity in teaching English that must be done by the teacher. Some teachers find problems in teaching reading comprehension. The problem is that the teacher cannot know exactly the students' prior knowledge. Although the teacher has taught some materials which are related to the topic that will be discussed, the teacher cannot make sure that all the students are able to understand the material well. It becomes a serious problem in teaching reading comprehension as prior knowledge is very important to the students' reading comprehension (National Research Council, 2004).

Brummer and Macceca (2008) stated that read, cover, remember, retell strategy is an effective strategy to help readers at all levels who think that good reading is reading quickly. There are some effective thing from read, cover, remember, retell strategy that involves alternating and summarizing or explaining. In this case read, cover, remember and retell strategy can reduce the opportunity of one participant is simply a passive recipient seem likely to be better for both motivation and learning. The framework of Read, Cover, Remember, and Retell (RCRR) Strategy like a house has a phase to get the best skill in reading comprehension. The strategy of RCRR are: first is Read, the strategy is only read the text with a small portion and think about what you are reading from part of the story or text. Second is Cover, the strategy is to explain and use your hand to cover some part of the story that you read and you must try to remember what you have read. The third is Remember, the strategy is to explain what you have remembered from the text and prepare the words to tell the part of story or text, and the last is Retell, the strategy is you must tell about the part of story or text by using your own words.

Yulimariza (2013) gave some procedures about read, cover, remember, and retell strategy in reading comprehension as follow: the first is a teacher may divide the students into some groups. Second is students select a small text on a page that can be covered by their hand. The third is teacher or students determine the topic of the text. Fourth is have students silently read as much text as they can and cover the words with one hand. The fifth is to ask each group to read and discuss the text that they get. Sixth is after reading, ask them to cover the text again with their hand and think about what they have read. Seventh is the students must remember what they have just read. Eighth is have students retell the section they just read, either silently or with a partner and the last is summarizing is beneficial to readers in several ways.

Amira (2018) said that Read, Cover, Remember, Retell Strategy has some advantages. The first advantage of making the students has an opportunity for giving mutual support and stimulation. Second is, in addition, students are making a connection, sequencing events, and considering causes of action and the effects of this action and the last advantage is this strategy is a way which provides understanding and memorizing in the learning process. 


\section{Related Study}

A study was conducted by Dahler, Putra., Zaim \& Fauzan (2019) entitled, "Using Read Cover Remember Retell (RCRR) in Teaching Reading Comprehension". The method of this research was quasi-experimental research, the population was the second-grade students of SMPN 16 Pekan Baru which amounted 240 students. The technique of collecting data was test. The technique used to analyze the test was T-test, U-Mann Whitney and N-gain. They found out that there was a positive effect and the RCRR strategy was effective to improve students' reading comprehension of recount text.

Arinda (2018) was done a study entitled. "Using Read-Cover-Remember-Retell (RCRR) Technique to Improve the Hortatory Exposition Text Reading Skill of the Eleventh Graders of SMA Muhammadiyah 1 Kota Magelang in the School Year 2017/2018. She conducted a Classroom Action Research (CAR) which was divided into Pre-Cycle, Cycle I, and Cycle II and to collect the data, she used test and non-test (observation, questionnaire, and documentation). The result of the study showed the RCRR technique can increase the learning motivation and there was a great improvement of the hortatory exposition text reading skill of the students.

Daulay \& Simanjuntak (2018) was conducted a study entitled, "Improving Students' Ability in Reading Narrative Text Through Read, Cover, Remember, Retell (RCRR) Strategy at SMP Global Prima National Plus School Medan.” The study was conducted by using Classroom Action Research (CAR), both qualitative and quantitative were applied in this research. The quantitative data were taken from the students score in reading narrative text and the qualitative data obtained from the observation of the students' activity in learning process. They have proved that RCRR (Read, Cover, Remember, Retell) strategy improved the students' ability in reading narrative text.

Amira (2018) was done a study entitled, "The Implementation of RCRR (Read, Cover, Remember, Retell) Strategy to improve Students' Achievement in Reading Comprehension. She used Classroom Action Research (CAR) in this study. Descriptive qualitative and quantitative design were applied. The quantitative data were taken from the students' scores in reading comprehension, while the qualitative was obtained from the observation of the students' activity and teacher's performance in learning process. Based on the result, the RCRR strategy improved the students' achievement in reading comprehension.

Another study was conducted by Djunaidi, Noviati \& Oktariani (2017) entitled, "The Application of RCRR (Read, Cover, Remember, Retell) Strategy in Teaching Reading Descriptive Text to the Eight Grade Students of State Junior High School 50 Palembang. The research was pre-experimental method with one group pretest-postetst design. It was taken by using cluster random sampling method. The data were collected by using written test. They have found that the RCRR strategy was effective in teaching reading descriptive text and could increase students' ability and students score in reading descriptive text. 


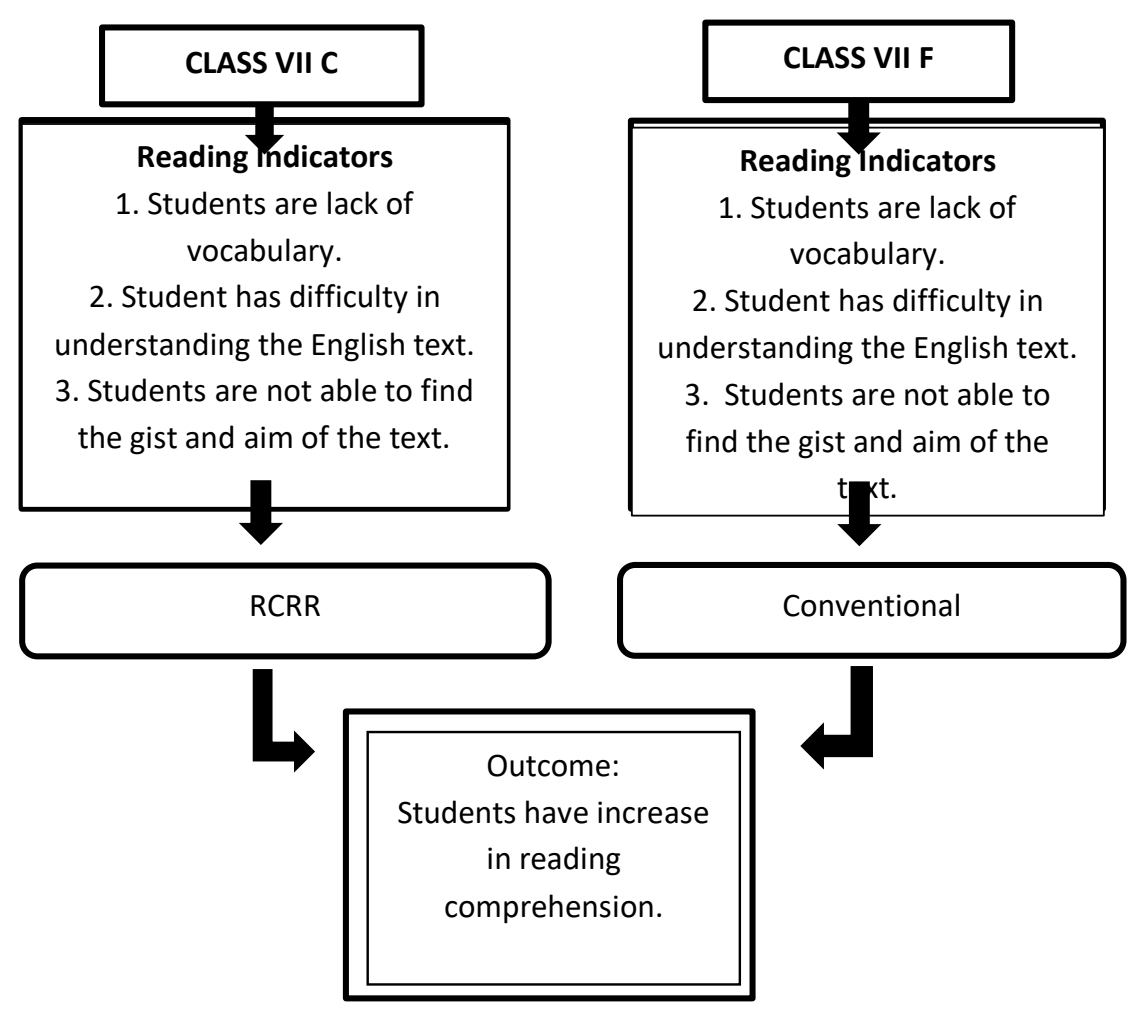

Fig.1. Conceptual Framework

\section{Methodology}

This study applied an experimental research design. Experimental research designs are the primary approach used to investigate causal (cause/effect) relationships and to study the relationship between one variable and another (Fraenkel, Wallen \& Hyun, 2012). The design was applied pre-test and post-test for both the experimental group and the conventional group. This research was a true-experimental research, which was research about cause and effect design.

This investigation was about how the students' reading comprehension can be improved through the use of RCRR strategy so the pre-test was used before the treatment was being implied to evaluate their pre-existing comprehension. The post-test was administered at the end of the session to see whether there was an improvement in the students' reading comprehension achievement after they have been taught reading comprehension through RCRR strategy. Table 3.1 presented the design of research and treatments (Creswell, 2003).

Table 3.1

Research Design

\begin{tabular}{|c|c|c|c|}
\hline Sample & Pre-test & Treatment & Post-test \\
\hline G1 & O & X1 & O \\
\hline G2 & O & & O \\
\hline
\end{tabular}

Where:

G1: Experimental group 
G2: Conventional group

$\mathrm{X} 1$ : Treatment of using RCRR

O: Reading Test

The Population and Sample

The population of this study was students at SMPN 10 Cimahi. The samples were grade VII A and B. The range of age were about 13-15 years old. Each of the class consisted about 30-35 students. One of the groups was the experimental group and the other group was the conventional group. The student in the experimental group was taught using RCRR strategy and the students in the conventional group were taught without using RCRR.

Research Instrument

Instruments were used to facilitate this research and to collect the data or information which was important to find the result of this research, the pre-test and post-test were used, and both samples were acquired the same instruments. A pilot test was administered to validate the test. Below was the explanation of the instruments:

Lesson Plan

The lesson plan was designed as a guidance for running the detailed description of the course step-by-step. Lesson plan are designed to help to focus on the goals that need to be achieved. This lesson plan included the students and teachers' activities, the teacher's approaches, the time allocation, and the material used in the classroom.

\section{Pilot Test}

The pilot test was administered before giving the pre-test. The test was a reading test; adopted from some sources and students' textbook. This test was validated by using Anates. Anates was used to facilitate in order to do the reliability test, difficulty level test, validity test and analyze the discrimination index. The pilot test consisted of 50 multiple-choice questions.

Pre-test

After administered the pilot test, a pre-test was conducted to get the achievement before the treatment was given. The purpose of the pre-test was to know the initial students' reading comprehension level.

\section{Treatment}

The treatment was only given to the experimental group. Before the treatment was conducted, a-week observation on the class was done and was taught the conventional class by using the usual materials and method used by the classroom teacher. The RCRR strategy is a reading strategy that helped the students to tackle textbook material in a strategic manner. The RCRR was used to improve the students' reading comprehension.

Table 1. Procedures of the Treatment

\begin{tabular}{|c|c|}
\hline $\begin{array}{c}\text { Class A (Conventional) } \\
\text { The teacher introduces about the } \\
\text { material what will be taught. }\end{array}$ & $\begin{array}{l}\text { Class B (Experiment) } \\
\text { The teacher introduces the } \\
\text { effectiveness of RCRR procedures in } \\
\text { improving reading comprehension. }\end{array}$ \\
\hline $\begin{array}{c}\text { The teacher explains the material and } \\
\text { give the students worksheet to be done. }\end{array}$ & \begin{tabular}{l} 
Stage 2: Read \\
\hline
\end{tabular} \\
\hline
\end{tabular}




\begin{tabular}{|c|c|}
\hline & $\begin{array}{l}\text { As the first step of RCRR } \\
\text { procedures, read. Read a section of text } \\
\text { that is only as big as your hand can } \\
\text { cover. It can be an individual reading or } \\
\text { group reading. }\end{array}$ \\
\hline $\begin{array}{l}\text { The teacher makes a discussion with the } \\
\text { whole class and share the answers. }\end{array}$ & $\begin{array}{l}\text { Stage 3: Cover } \\
\text { When they have finished reading } \\
\text { the text, they can cover up the text they } \\
\text { have read. They can write them on sticky } \\
\text { notes, the teacher can collect them and } \\
\text { the students make a list of the students' } \\
\text { words. }\end{array}$ \\
\hline $\begin{array}{l}\text { The teacher writes down the points from the } \\
\text { worksheet. }\end{array}$ & $\begin{array}{l}\text { Stage } 4 \text { : Remember } \\
\text { The students think about what } \\
\text { they just read, and tried to remember } \\
\text { what they write. }\end{array}$ \\
\hline $\begin{array}{l}\text { The teacher reviews the lesson with the } \\
\text { whole class. }\end{array}$ & $\begin{array}{l}\text { Stage 5: Retell } \\
\text { The students must be able to } \\
\text { remember what they write and } \\
\text { remember. The students try to retell a }\end{array}$ \\
\hline
\end{tabular}

\section{Post-test}

After the treatment, a post-test was given to the students. This test was used to see the improvement of the students in reading comprehension through the use of RCRR. The posttest achievement was given to the students to be compared to the pre-test scores.

\section{Data Collection Procedures}

To collect the data, the pre-test, treatment, post-test, and scoring were administered then got the result of each test. The first was the pre-test which was administered to both groups in order to find out the groups' achievement before the treatment was given. After the pre-test was conducted to the students, the treatment was given to the experimental group according to the procedures of the treatment. Then, the post-test was given to both groups after giving the treatment. The third was scoring all the tests given, by using the rubric as the guideline to score the test. Both pre-test and post-test scores were compared.

\section{Statistic Procedures}

The statistical program used in analyzing the data were SPSS, States, and Microsoft Excel.

Validity Test

The validity test aimed to find out if the instrument test was suitable to be used in the research. The following formula was used to test the validity of the instrument (Arif, 2014).

Where:

$$
r_{x y}=\frac{n \sum X Y\left(\sum X\right)\left(\sum Y\right)}{\sqrt{n\left(\sum X^{2}-\left(\sum X\right)^{2}\right)-\left(n\left(\sum Y^{2}-\left(\sum Y\right)^{2}\right)\right.}}
$$

$\mathrm{r}_{\mathrm{xy}} \quad$ : Correlation Coefficient

$\mathrm{X}$ : Item Score 
Y : Total Score

$\mathrm{N} \quad$ : Number of Participants

Suherman (2003) figured out the criteria of validity test that is reflected in table 2.

Table 2. Validity Criteria

\begin{tabular}{|c|c|}
\hline$r_{x y}$ & Interpretation \\
\hline $0,80<\operatorname{rxy} \leq 1,00$ & Very high \\
\hline $0,60<\operatorname{rxy} \leq 0,80$ & High \\
\hline $0,40<\operatorname{rxy} \leq 0,60$ & Moderate \\
\hline $0,20<\operatorname{rxy} \leq 0,40$ & Low \\
\hline $0,00<\operatorname{rxy} \leq 0,20$ & Very low \\
\hline rxy $\leq 0,00$ & Not valid \\
\hline
\end{tabular}

The result was as follow:

Table 3. Validity Question

\begin{tabular}{|c|c|c|}
\hline Number of Question & $r_{x y}$ & Interpretation \\
\hline- & $0,80<\mathrm{rxy} \leq 1,00$ & Very high \\
\hline $17,31,43$. & $0,60<\mathrm{rxy} \leq 0,80$ & High \\
\hline $\begin{array}{c}2,12,15,16,22,24,25, \\
37,40,42,44 .\end{array}$ & $0,40<\mathrm{rxy} \leq 0,60$ & Moderate \\
\hline $\begin{array}{c}1,5,7,13,20,21,23,28, \\
32,35,36,38,45,47,49 .\end{array}$ & $0,20<\mathrm{rxy} \leq 0,40$ & Low \\
\hline $\begin{array}{c}4,6,8,9,18,19,26,27, \\
29,30,46 .\end{array}$ & $0,00<\mathrm{rxy} \leq 0,20$ & Very low \\
\hline $\begin{array}{c}3,10,11,14,33,34,39, \\
41,48,50 .\end{array}$ & $\mathrm{rxy} \leq 0,00$ & Not valid \\
\hline
\end{tabular}

Based on the result above, questions that were valid if the score was larger than 0.00 . From the table calculation, there were 25 items were valid. There were 3 items were high, 11 items were moderate, 15 items were low, 11 items were very low, 10 items were not valid.

\section{Reliability Test}

Reliability of a test according to Masriyah (1999) is the level of stability or the stability of the measurement results. A reliable measuring tool is a measuring instrument used to measure the same thing over and over again, and the results are relatively the same. The formula used to find the reliability of the instrument was alpha's formula (Arikunto, 2012).

Where:

$$
r_{11}=\left(\frac{n}{n-1}\right)\left(1-\frac{\sum s_{1}{ }^{2}}{s_{t}{ }^{2}}\right)
$$

$$
\begin{array}{ll}
\mathrm{r}_{11} & : \text { Reliability of the instrument } \\
\mathrm{n} & : \text { Total number of questions } \\
\sum_{\mathrm{S}_{\mathrm{t}}{ }^{2}}{ }^{2} & : \text { Total score of each question variance } \\
& \text { : Variance total score }
\end{array}
$$

The criteria of reliability level according to Arif (2014) are shown in table 4. 
Table 4. Classification of Reliability

\begin{tabular}{|c|c|}
\hline Coefficient Reliability & Interpretation \\
\hline $0,80<\mathrm{r} 11 \leq 1,00$ & Very High \\
\hline $060<\mathrm{r} 11 \leq 0,80$ & High \\
\hline $0,40<\mathrm{r} 11 \leq 0,60$ & Moderate \\
\hline $0,20<\mathrm{r} 11 \leq 0.40$ & Low \\
\hline $0,00<\mathrm{r} 11 \leq 0,20$ & Very Low \\
\hline $\mathrm{r} 11 \leq 0,00$ & Not valid \\
\hline
\end{tabular}

The calculation result of the reliability test was 0.50 . It meant it has a moderate level.

Discrimination Index

Discriminate index according to Ratumanan (2003) stated how far the ability of the question is able to distinguish between the group of smart students and the weak group. The differentiation of the test items was calculated by the formula:

$$
D P=\frac{N B_{a}-N B_{b}}{N S_{a}} \quad \text { or } \quad D P=\frac{N B_{a}-N B_{b}}{N S_{b}}
$$

Where:

D : Discrimination index

$\mathrm{N}$ : Number of the test participants

$\mathrm{N}_{\mathrm{A}} \quad$ : Number of a lower group participant

$\mathrm{N}_{\mathrm{B}} \quad$ : Number of lower group participant

$\mathrm{B}_{\mathrm{A}} \quad$ : Number of upper group participants who answered the question correctly

$\mathrm{B}_{\mathrm{A}} \quad$ : Number of lower group participants who answered the question correctly

$\mathrm{P}_{\mathrm{A}}=\mathrm{B}_{\mathrm{A}} \quad$ : the proposition of upper group students who correctly answer the test $\mathrm{J}_{\mathrm{A}} \quad$ item

$\mathrm{P}_{\mathrm{B}}=\mathrm{B}_{\mathrm{B}} \quad$ : the proposition of lower group students who correctly answer the test $\mathrm{J}_{\mathrm{B}}$ item

value of discrimination index from Arikunto (2009) was employed to interpret the distinguishing clarification, and it was shown in table 5.

Table 5. Criteria of Discrimination Index

\begin{tabular}{|c|c|}
\hline Discrimination Index & Interpretation \\
\hline $0,00 \leq D I \leq 0,20$ & Poor \\
\hline $0,21 \leq D I \leq 0,40$ & Sufficient \\
\hline $0,41 \leq D I \leq 0,70$ & Good \\
\hline $0,71 \leq D I \leq 1,00$ & Very Good \\
\hline
\end{tabular}

The result was as follow: 
Table 6. Discrimination Index

\begin{tabular}{|c|c|c|}
\hline Number of Questions & Discrimination Index & Interpretation \\
\hline $\begin{array}{c}3,6,7,8,9,10,11,14,16, \\
18,21,24,26,30,33,34,39, \\
41,46,48,50 .\end{array}$ & $0,00 \leq D I \leq 0,20$ & Poor \\
\hline $\begin{array}{c}4,19,20,22,29,31,32,35, \\
36,38,44,49 .\end{array}$ & $0,21 \leq D I \leq 0,40$ & Sufficient \\
\hline $\begin{array}{c}1,2,5,12,13,15,17,23,25, \\
27,28,37,40,42,43,45,47 .\end{array}$ & $0,41 \leq D I \leq 0,70$ & Good \\
\hline- & $0,71 \leq D I \leq 1,00$ & Very Good \\
\hline
\end{tabular}

According to the table above there were 21 items in the poor category, 12 questions in sufficient category, 17 items in the good category, and 0 items in very good.

Level of Difficulty

The level of difficulty was expressed in the difficulty index (number of difficulty index) which showed the proportion of students that correctly answer the question (Masriyah, 1999). The bigger the index of difficulty, the easier it is. Conversely, the smaller the difficulty index, the more difficult the item is. Arikunto (2009) figured out that the difficulty index of a test item can be calculated by the formula:

$$
P=\frac{C}{N P}
$$

Where:

$\mathrm{P} \quad$ : Difficulty index of test item

C : The number of students who answered correctly

NP : The number of participants in the test

The classification of difficulty level according to Arikunto (2009) was shown in table 7.

Table 7. Criteria of Difficulty Level

\begin{tabular}{|c|c|}
\hline Level of Difficulty & Interpretation \\
\hline $0,71 \leq D f l \leq 1,00$ & Easy \\
\hline $0,31 \leq D f l \leq 0,70$ & Moderate \\
\hline $0,00 \leq D f l \leq 0,30$ & Difficult \\
\hline$<0,00$ & Very difficult \\
\hline
\end{tabular}

The result was as follow:

Table 8. Difficulty Level

\begin{tabular}{|c|c|c|}
\hline Number & Index of Difficulty & Difficulty Degree \\
\hline- & $0,71 \leq D f l \leq 1,00$ & Easy \\
\hline $1,3,4,5,10,11,12,13$, & $0,31 \leq D f l \leq 0,70$ & Moderate \\
$\begin{array}{c}14,23,29,30,32,33,34, \\
35,36,38,39,41,45,46, \\
47,48,49,50 .\end{array}$ & \\
\hline $\begin{array}{c}2,6,8,9,20,21,25,27, \\
28,37,40,42,44 .\end{array}$ & $0,00 \leq D f l \leq 0,30$ & Difficult \\
\hline
\end{tabular}




\begin{tabular}{|c|c|c|}
\hline $7,15,16,17,18,19,22$, & $<0,00$ & Very difficult \\
$24,26,31,43$. & & \\
\hline
\end{tabular}

According to the result above that had had an index of difficulty level. Based on the result of the table calculation above, 26 items were moderate, and 13 items that were difficult and 11 items that were very difficult.

The Result of Recapitulation of Pilot Test

This research used 25 questions for pre-test and post-test. To analyze the result of the data, Anates program was used. The recapitulation of the test result can be seen in table 9 .

Table 9. The Recapitulation of Pilot Test

\begin{tabular}{|c|c|c|c|}
\hline $\begin{array}{l}\text { Number of } \\
\text { question }\end{array}$ & Validity & Difficulty level & Discrimination \\
\hline 1 & Low & Moderate & Good \\
\hline 2 & Moderate & Difficult & Good \\
\hline 3 & Not Valid & Moderate & Poor \\
\hline 4 & Very Low & Moderate & Sufficient \\
\hline 5 & Low & Moderate & Good \\
\hline 6 & Very Low & Difficult & Poor \\
\hline 7 & Low & Very Difficult & Poor \\
\hline 8 & Very Low & Difficult & Poor \\
\hline 9 & Very Low & Difficult & Poor \\
\hline 10 & Not Valid & Moderate & Poor \\
\hline 11 & Not Valid & Moderate & Poor \\
\hline 12 & Moderate & Moderate & Good \\
\hline 13 & Low & Moderate & Good \\
\hline 14 & Not Valid & Moderate & Poor \\
\hline 15 & Moderate & Very Difficult & Good \\
\hline 16 & Moderate & Very Difficult & Poor \\
\hline 17 & High & Very Difficult & Good \\
\hline 18 & Very Low & Very Difficult & Poor \\
\hline 19 & Very Low & Very Difficult & Sufficient \\
\hline 20 & Low & Difficult & Sufficient \\
\hline 21 & Low & Difficult & Poor \\
\hline 22 & Moderate & Very Difficult & Sufficient \\
\hline 23 & Low & Moderate & Good \\
\hline 24 & Moderate & Very Difficult & Poor \\
\hline 25 & Moderate & Difficult & Good \\
\hline 26 & Very Low & Very Difficult & Poor \\
\hline 27 & Very Low & Difficult & Good \\
\hline 28 & Low & Difficult & Good \\
\hline 29 & Very Low & Moderate & Sufficient \\
\hline 30 & Very Low & Moderate & Poor \\
\hline 31 & High & Very Difficult & Sufficient \\
\hline 32 & Low & Moderate & Sufficient \\
\hline 33 & Not Valid & Moderate & Poor \\
\hline 34 & Not Valid & Moderate & Poor \\
\hline
\end{tabular}




\begin{tabular}{|c|c|c|c|}
\hline 35 & Low & Moderate & Sufficient \\
\hline 36 & Low & Moderate & Sufficient \\
\hline 37 & Moderate & Difficult & Good \\
\hline 38 & Low & Moderate & Sufficient \\
\hline 39 & Not Valid & Moderate & Poor \\
\hline 40 & Moderate & Difficult & Good \\
\hline 41 & Not Valid & Moderate & Poor \\
\hline 42 & Moderate & Difficult & Good \\
\hline 43 & High & Very Difficult & Good \\
\hline 44 & Moderate & Difficult & Sufficient \\
\hline 45 & Low & Moderate & Good \\
\hline 46 & Very Low & Moderate & Poor \\
\hline 47 & Low & Moderate & Good \\
\hline 48 & Not Valid & Moderate & Poor \\
\hline 49 & Low & Moderate & Sufficient \\
\hline 50 & Not Valid & Moderate & Poor \\
\hline
\end{tabular}

Based on the recapitulation test, this research used 25 questions for pre-test and posttest. They were questions number: $1,2,12,13,15,16,17,20,21,22,23,24,25,28,31,35$, $36,37,38,40,42,43,44,45$, and 47 . Those were based on the result of questions analysis; that the 25 questions were able to measure the students' ability in improving students' reading comprehension and fulfill the indicators of reading comprehension.

Non-test Instrument (Student's Response Questionnaire)

The non-test instrument was done by using a questionnaire in order to know the students' response toward the lesson and strategy that will be used in the teaching-learning process. This questionnaire was given after the post-test was conducted. The statements in the questionnaire were about RCRR and Conventional method in improving students' reading comprehension ability.

There were four alternate answers in this questionnaire, those are: Strongly Agree (SA), Agree (A), Disagree (D), Strongly Disagree (SD). The completed questionnaire was classified as follows:

1. The calculation of number of positive responses for each item was on positive items, Strongly Agree (SA), Agree (A), and the negative items, Disagree (D), Strongly Disagree (SD).

2. The Percentage was calculated using the following presentation formula as follows:

Table 10. Scoring of Student's Response with Positive Item Type

\begin{tabular}{|c|c|}
\hline Alternative Answer & Score \\
\hline Strongly Agree & 4 \\
\hline Agree & 3 \\
\hline Slightly agree & 2 \\
\hline Disagree & 1 \\
\hline
\end{tabular}
follow.

For the questionnaire with negative item, the scoring reversed, so the criteria was as 
Table 11. Scoring of Student's Response with Negative Item Type

\begin{tabular}{|c|c|}
\hline Alternative Answer & Score \\
\hline Strongly Agree & 1 \\
\hline Agree & 2 \\
\hline Slightly agree & 3 \\
\hline Disagree & 4 \\
\hline
\end{tabular}

(Arikunto, 1991)

The questionnaire had 10 statements, so the maximum score for the questionnaire was 40 and the minimum score was 10 . After the data was obtained, then the percentage of student response was calculated with this formula:

Where:

$$
R_{i}=\frac{S_{i}}{S_{\text {maks }}} \times 100
$$

$\mathrm{R}_{\mathrm{i}} \quad=$ Student $\mathrm{i}$ response score

$\mathrm{S}_{\mathrm{i}} \quad=$ Total of score item of student $\mathrm{i}$

$\mathrm{S}_{\max }=$ Maximum score

Table 12. Interpretation of students' Response

\begin{tabular}{|c|c|}
\hline Degree in Persentage & Interpretation \\
\hline $80 \leq \mathrm{t} \leq 100$ & Very Good \\
\hline $60 \leq \mathrm{t} \leq 80$ & Good \\
\hline $40 \leq \mathrm{t} \leq 60$ & Moderate \\
\hline $20 \leq \mathrm{t} \leq 40$ & Bad \\
\hline $\mathrm{t} \leq 20$ & Very Bad \\
\hline
\end{tabular}

Data Analysis

(Arikunto, 2012)

The researcher was used statistical package for social science (SPSS) to analyze the data. SPSS is a computer program for statistic computation. The level of significance $\square=0.05$

\section{Normalized Gain}

To determine the improvement of students' reading comprehension, the researcher performed an analysis of the results of the pre-test and post-test. Analyzing performed by using Normalized Gain (Hake, 1999).

$$
\mathrm{g}=\frac{\text { \%post }- \text { test }-\% \text { pre-test }}{100 \%-\% \text { pre-test }}
$$

Where:

$\mathrm{G} \quad$ : Average normalized gain

$\%$ pre-test : Percentage of pre-test scores

$\%$ post-test : Percentage of post-test scores

According to Hake (2007), the criteria of normalized gain was shown below.

Table 13. The Criteria of Normalized Gain

\begin{tabular}{|l|l|}
\hline Gain $(\mathrm{g})$ & Category \\
\hline $0.71<\mathrm{g} \leq 1.00$ & High \\
\hline $0.31<\mathrm{g} \leq 0.70$ & Moderate \\
\hline $0.00 \leq \mathrm{g} \leq 0.30$ & Low \\
\hline
\end{tabular}




\section{Normality Test}

Normality test was being conducted to see whether the population of the data collected was normally distributed or not. To test the normality of the population the researcher used the Shapiro-Wilk. To calculate the data using SPSS. The formula was (Ruseffendi, 1998):

Where:

$$
\mathrm{W}=\frac{\left(\sum a_{i} x_{i}\right)^{2}}{\sum\left(x_{i}-\bar{x}\right)^{2}}
$$

W : Test statistic

$\mathrm{X}_{\mathrm{i}}$ : statistic order X1, X2, X3 .., Xn

$\mathrm{A}_{\mathrm{i}}$ : Constant generated from the average value (mean), variance, and covariance structure sample distribution of and from a normal distribution.

$\mathrm{X}$ : The mean of sample data

The hypothesis was as follow:

$H o$ : The data population is normally distributed

$\mathrm{Ha}$ : The data population is not normally distributed

The criteria of Normality test if the data were analyzed with SPSS:

a. Data were normally distributed if sig. value is larger $(>)$ than $\alpha(0.05)$, or Ho is not rejected.

b. Data were not normally distributed if sig. value is lesser or equal $(\leq)$ or $\alpha(0.05)$, and then Ho is rejected.

\section{Homogeneity Test}

To determine whether the population variances were homogeny or not which meant that having the same basic qualities, the researcher used the homogeneity test based on the result of the normality test (Uyanto, 2009). The formula was:

Where:

$$
F=\frac{S_{1}^{2}}{S_{2}^{2}}
$$

$\mathrm{F} \quad$ : value (variance variable data)

$\mathrm{S}_{1}{ }^{2} \quad$ : the larger variance

$\mathrm{S}_{2}{ }^{2} \quad$ : the smaller variance

The hypothesis will be used are:

Ho : The population variances are homogeny

$\mathrm{Ha}$ : The population variances are not homogeny

The criteria of Homogeneity test if the data were analyzed with SPSS:

a. The population variances were homogeny if sig. Value $>\alpha(0.05)$, then Ho was not rejected.

b. The population variances were not homogeny if sig. Value $\leq \alpha(0.05)$, then Ho was rejected.

\section{Mean Difference Test}

The significant value was used either T-Test or U-Test to determine if there was a significant difference or not between both data (Different mean test). This step was answered the second statement for the statement of the problem. If the two populations were homogeneous, the sample T-test was used with the formula (Supranto, 2009). 
Where:

$$
t=\frac{\overline{x_{1}}-\overline{x_{2}}}{S D \sqrt{\frac{1}{n_{1}}+\frac{1}{n_{2}}}} \quad S D=\sqrt{\frac{\left(n_{1}-1\right) s_{1}^{2}+\left(n_{2}-2\right) s_{2}^{2}}{n_{1}+n_{2}-2}}
$$

$\overline{x_{1}}$ : Average students' score (experimental class)

$\overline{x_{2}}$ : Average students' score (conventional class)

$n_{1}$ : Number of students (experimental class)

$n_{2}:$ Number of students in (conventional class)

$s_{1}$ : Variance of students' score (experimental class)

$s_{2}$ : Variance of students; score (conventional class)

However, if the data was not normality distributed, then the two-different test average used as a non-parametric test or Mann-Whitney, with formula was below (Supranto, 2009).

Where:

$$
U=n_{1 n_{2}}+\frac{n_{2}\left(n_{2}+1\right)}{2}-\sum_{i=n_{1}+1}^{n_{2}} R_{1}
$$

$\mathrm{U}$ : Mann-Whitney U test

$\mathrm{n}_{1}$ : Sample size one

$\mathrm{n}_{2}$ : Sample size two

$\mathrm{R}_{\mathrm{i}}$ : Rank of the sample size

The hypothesis of the different mean test was as follow:

$H_{o}$ : There was no significant difference in the improvement of reading comprehension between the experimental group and the conventional method.

$H_{a}$ : There was a significant difference in the improvement of reading comprehension between the experimental group and the conventional method.

The criteria of Different Mean test if the data as analyzed with SPSS:

a. $\mathrm{H}_{\mathrm{o}}$ was not rejected if the sig. value $>\alpha(0.05)$, meant that there was no significant difference in the improvement of students' reading comprehension.

b. $\mathrm{H}_{\mathrm{o}}$ was rejected if the sig. value $\leq \alpha(0.05)$, meant that there was a significant difference in the improvement of students' reading comprehension.

\section{Discussion and findings}

Data Analysis

In analyzing the data, the researcher used Microsoft Excel and Statistical Program, SPSS. The result of pre-test and post-test of each class can be seen in the following table:

Table 14. Pre-Test, Post Test, Standard Deviation, and Normalized Gain

\begin{tabular}{|c|c|c|c|c|}
\hline \multirow{2}{*}{} & \multicolumn{2}{|c|}{ Control } & \multicolumn{2}{c|}{ Experimental } \\
\cline { 2 - 5 } & Mean & St. Deviation & Mean & St. Deviation \\
\hline Pre-Test & 38.73 & 10.027 & 40.27 & 12.191 \\
\hline Post Test & 67.07 & 7.367 & 73.47 & 6.279 \\
\hline Normalized Gain & .460776 & .0936729 & .553128 & .0143782 \\
\hline
\end{tabular}


Based on the result in table 4.1, it can be seen the mean pre-test of the conventional was 38.73 with st.deviation of 10.027 and post-test was 67.07 with st.deviation of 7.367 . For the experimental group, the mean of the pre-test was 40.27 with st.deviation of 12.191 and posttest was 67.07 with st.deviation of 7.367 and the normalized gain from the conventioanl was 0.460776 in moderate category and the normalized gain from the experimental group was 0.553128 in the moderate category. Based on the increase of the mean and decrease the st.deviation from pre-test to post-test of both groups and the normalize gain from both groups, it can be concluded that there is an improvement on students' reading comprehension ability.

Test of Normality Pre-test

In order to know whether the data population of pre-test was normally distributed or not, the normality test was conducted. After got the normality then the researcher did the homogeneity test to find out the population was homogenous or not.

Table 15. The normality Test Result for Pre-test Score

\begin{tabular}{|c|c|c|c|}
\hline \multirow{2}{*}{ Group } & \multicolumn{3}{|c|}{ Shapiro-Wilk } \\
\cline { 2 - 4 } & Statistic & Df & Sig. \\
\hline Control & .852 & 30 & .001 \\
Experimental & .935 & 30 & .067 \\
\hline
\end{tabular}

This research used the output from the Shapiro-Wilk. If both data had p. Value (sig) > $\alpha=0.05$. It means the data were normally distributed and if the $\mathrm{p}$. Value (sig) $\leq \alpha=$ conventional was not normally distributed, where the significant value of the conventional was $0.001<0.05$ and the experimental group was normally distributed, where the significant value of experimental group was $0.067>0.05$. Table 4.2 showed the result of the normality test of pre-test from both classes.

Test of Homogeneity of Variance for Pre-test

To see the homogeneity of population variances, the homogeneity test was conducted.

Table 16. The Homogeneity test result for pre-test score

\begin{tabular}{|c|c|c|c|}
\hline Lavene Statistic & df1 & df2 & Sig. \\
\hline .338 & 1 & 58 & .563 \\
\hline
\end{tabular}

The data is homogeneous if $\mathrm{p}$. Value (sig) $>\alpha=0.05$ it meant data was homogeneous and if $\mathrm{p}$-Value (sig) $\leq \alpha=0.05$ it meant data was not homogeneous. Based on the data, the significant value was $0.563>0.05$, so it meant that the population variances were homogenous. The result can be seen in table 16

Hypothesis Testing for Pre-test

Based on the result, where the data was not normally distributed, the researcher used the Mann-Whitney Test. 
Table 17. The result of the Mann- Whitney Test - Test Statistic ${ }^{a}$

\begin{tabular}{|l|l|}
\hline & Gain \\
\hline Mann-Whitney U & 403.000 \\
Wilcoxon & 868.000 \\
Z & -.705 \\
Asymp. Sig. (2.tailed) & .481 \\
\hline
\end{tabular}

According to the data shown on table 17, it showed $0.481>0.05$. It means that Ho is not rejected. Therefore, it was concluded that there is no significant difference for the results of initial ability between conventional and experimental group.

Test of Normality for Gain Score

The normality test for the result of the gain score.

Table 18. The Normality Test Result for Normalized Gain Score

\begin{tabular}{|c|c|c|c|}
\hline \multirow{2}{*}{ Group } & \multicolumn{3}{|c|}{ Shapiro-Wilk } \\
\cline { 2 - 4 } & Statistic & Df & Sig. \\
\hline Control & .970 & 30 & .529 \\
Experimental & .955 & 30 & .226 \\
\hline
\end{tabular}

It can be concluded that the population of the data was normally distributed for both classes, it was because the significant value of conventional was $0.592>0.05$ and the significant value experimental group was $0.226>0.05$, can be seen on table 18

Test of Homogeneity Variance for Gain Score

To see the homogeneity of population variances, homogeneity was done. The result can be seen in table 19

Table 19. The Homogeneity Result for Normalized Gain Score

\begin{tabular}{|c|c|c|c|}
\hline Lavene Statistic & df1 & df2 & Sig. \\
\hline .923 & 1 & 58 & .341 \\
\hline
\end{tabular}

According to the data above, the significant value was $0.341>0.05$, so it meant that the population variances are homogenous.

Independent Sample Test for Gain Score

Since the data was normally distributed, independent sample t-test was conducted. 
Table 20. The Independent Sample T-test Result for Gain Score

\begin{tabular}{|c|c|c|c|c|c|}
\hline & \multicolumn{2}{|c|}{$\begin{array}{l}\text { Levene's Test for } \\
\text { Equality of Variences }\end{array}$} & \multirow[b]{2}{*}{$\mathrm{T}$} & \multirow[b]{2}{*}{ Df } & \multirow[b]{2}{*}{$\begin{array}{l}\text { Sig.(2- } \\
\text { tailed) }\end{array}$} \\
\hline & $\mathrm{F}$ & Sig. & & & \\
\hline $\begin{array}{l}\text { Gain Equal } \\
\text { variences } \\
\text { assumed } \\
\text { Equal variences } \\
\text { not assumed }\end{array}$ & .923 & .341 & -4.133 & 56.388 & 0.00 \\
\hline
\end{tabular}

From the result, the significant value was $0.00<0.05$, so that meant Ho is rejected, then it becomed the answer of the second statement of the problem that there is a significant difference between those who are taught using RCRR and those who are taught using conventional, can be seen on table 20 .

Questionnaire

The additional data required for the present study were collected through administering a questionnaire to the subjects in order to know their response toward RCRR. The results were explained in the table below:

Table 21. Questionnaire

\begin{tabular}{|c|c|c|c|c|c|c|c|}
\hline Subject & $\begin{array}{c}\text { Strongly } \\
\text { Agree (A) }\end{array}$ & $\begin{array}{c}\text { Agree } \\
(\mathrm{B})\end{array}$ & $\begin{array}{c}\text { Slightly } \\
\text { Agree (C) }\end{array}$ & $\begin{array}{c}\text { Disagree } \\
(\mathrm{D})\end{array}$ & $\begin{array}{c}\text { Total } \\
\text { Score }\end{array}$ & $\begin{array}{c}\text { (Total } \\
\text { score/40) } \\
\text { x 100 }\end{array}$ & Interpretation \\
\hline 1 & 4 & 20 & 5 & 4 & 33 & 82.5 & Very Good \\
\hline 2 & 4 & 19 & 2 & - & 25 & 62.5 & Good \\
\hline 3 & 7 & 20 & 2 & 2 & 31 & 77.5 & Good \\
\hline 4 & 1 & 22 & 3 & 1 & 27 & 67.5 & Good \\
\hline 5 & 20 & 9 & 6 & 2 & 33 & 82.5 & Very Good \\
\hline 6 & 7 & - & 10 & 2 & 19 & 47.5 & Moderate \\
\hline 7 & 1 & - & 13 & 4 & 18 & 45 & Moderate \\
\hline 8 & 9 & 12 & 6 & 2 & 29 & 72.5 & Good \\
\hline 9 & 4 & 17 & 5 & 6 & 32 & 80 & Very Good \\
\hline 10 & 5 & 19 & 3 & - & 27 & 67.5 & Good \\
\hline 11 & 5 & 20 & 4 & 3 & 32 & 80 & Very Good \\
\hline 12 & 4 & 21 & - & 1 & 26 & 65 & Good \\
\hline 13 & 29 & - & 3 & 2 & 34 & 85 & Very Good \\
\hline 14 & 3 & 20 & 3 & 2 & 28 & 70 & Good \\
\hline 15 & - & 20 & 2 & 2 & 24 & 60 & Modarate \\
\hline 16 & 4 & 4 & 10 & 3 & 21 & 52.5 & Moderate \\
\hline 17 & - & 23 & - & 3 & 26 & 65 & Good \\
\hline 18 & - & 23 & 2 & 6 & 31 & 77.5 & Good \\
\hline 19 & - & 24 & 1 & 2 & 27 & 67.5 & Good \\
\hline 20 & - & 21 & - & 5 & 26 & 65 & Good \\
\hline 21 & - & 24 & 6 & 1 & 31 & 77.5 & Good \\
\hline 22 & 1 & 22 & 1 & 2 & 26 & 65 & Good \\
\hline 23 & 3 & 21 & - & 2 & 26 & 65 & Good \\
\hline & & & & & & & \\
\hline
\end{tabular}




\begin{tabular}{|c|c|c|c|c|c|c|c|}
\hline 24 & 2 & 3 & 12 & 2 & 19 & 47.5 & Moderate \\
\hline 25 & 2 & 20 & 3 & 2 & 27 & 67.5 & Good \\
\hline 26 & 1 & 3 & 12 & 3 & 19 & 47.5 & Moderate \\
\hline 27 & 20 & 7 & - & - & 27 & 67.5 & Good \\
\hline 28 & 5 & 21 & 7 & - & 33 & 82.5 & Very Good \\
\hline 29 & 2 & 24 & - & 1 & 27 & 67.5 & Good \\
\hline 30 & 2 & 24 & 2 & 4 & 32 & 80 & Very Good \\
\hline
\end{tabular}

From the table above, the researcher might pulled out a conclusion as explained in the following table. So the result of the questionnaire was $68 \%$ good. It indicated a good response from the students

\section{Discussion}

The result of the data showed that there is a significant difference on students' reading comprehension between those who are taught using RCRR (Read, Cover, Remember and Retell) and those who were taught by using the conventional method. From the result of normalized gain showed that the students in the conventional group was 0.460776 and the students who are in the experimental group was 0.553128 . It can be concluded that the RCRR strategy was more applicable than the conventional method.

The data from the experimental group and conventional group classes showed that the students' reading comprehension increased, it can be seen from the mean of the pre-test score for the experimental was 40.27 and 38.73 for conventional and the mean of the post-test score was 73.47 for experimental and 67.07 for conventional. The researcher found that the treatment worked well for students to improve their reading comprehension. The students from both classes really enjoyed the learning process even though they found some difficulties. However, almost all the students really aimed to be able to read English so they can achieve their goals even though there are many difficult words that they do not understand but they still read to the end of the passage. In addition, the researcher also tried to do the best in teaching reading through fun ways and helped when the students when they were asking the meaning of some difficult words. To conclude, reading comprehension through RCRR strategy in the experimental group was better than the conventional method.

Nevertheless, looking up to the finding of the questionnaire result, the total of response were questionnaire is $68 \%$ good. It can be said that most of the students agreed that the implementation of RCRR was improving their reading comprehension.

\section{Conclusion}

Based on findings and analyzing the data, the researcher pulls out a conclusion that there is a significant difference on students' reading comprehension between students who are taught using RCRR (read, Cover, Remember and Retell) strategy and those students who are taught using the conventional method. The RCRR strategy is really effective to help students enjoy the reading, achieve their goals and learn a new vocabulary. 


\section{Recommendation}

1. For Teachers

It is recommended for English teachers to use RCRR strategy to teach reading comprehension in their classes because it has been proven by the researcher and the results also show that students' reading skill is improved.

2. For Students

For students, the RCRR strategy is useful and applicable to be used to improve their knowledge in reading comprehension, especially in vocabulary and reading mechanisms and RCRR strategies can help students to explore their ideas.

3. For Future Researchers

The researcher hopes that the results of this study can be used as additional references for future researchers at various levels and context.

\section{References}

Amira, F. (2018). The Implementation of RCRR (Read, Cover, Remember, Retell) Strategy to Improve Students Achievement in Reading Comprehension. Repository Universitas Muhammadiyah Sumatera Utara.

Anita (2013). The Effect of Using Read, Cover, Remember, Retell Strategy toward Reading Comprehension of Second Year Students at Senior High School Sukaramai Tapung Hulu Kampar Regency.

Arif, M. (2014). Penerapan aplikasi anates bentuk soal pilihan ganda. Jurnal Ilmiah Edutic, Vol. 1, No. 1, pp. 1-9

Arikunto, S (2009). Dasar-dasar evaluasi pendidikan. Jakarta: Bumi, Aksara.

Arinda, C. A. (2018). Using Read-Cover-Remember-Retell (RCRR) Technique to Improve the Hortatory Exposition Text Reading Skill of the Eleventh Graders of SMA Muhammadiyah 1 Kota Magelan in the School Year 2017/2018. A Paper.

Aruan, R., \& Sinur, V. (2012). Using Three Stay One Stray Strategy to Increase the Ability of the First Year of SMA Nurul Falah Students in Comprehending Narrative Text. A Paper. UNRI, Pekan Baru.

Brown, D. H. (2001). Principles of Language Learning and Teaching Fourth Edition. San Francisco: Addison Wesley Longman, Inc

Brummer, T., \& Macceca, S. (2008). Reading Strategies for Mathematics. Shell Education: McREL. By Combining Read, Cover, Remember, Retell and Three Two One.

Creswell, J. W. (2003). Research Design. California: Sage Publication

Dahler, Putra, R. J., Zaim, M., \& Fauzan, A. (2019). Using Read Cover Remember Retell (RCRR) in Teaching Reading Comprehension. Advances in Social Science, Education and Humanities Research, Volume 178. $1^{\text {st }}$ International Conference of Innovation in Education (ICoIE). 
Daulay, I. K., \& Simanjuntak, M. A. (2018). Improving Students' Ability in Reading Narrative Text Through Read, Cover, Remember, Retell (RCRR) Strategy at SMP Global Prima National Plus School Medan. Journal Imliah FKIP-UNIVA Medan Volume 5 No. 3. Edisi September - Desember 2018. ISSN 2406-7873.

Djunaidi, Noviati, Oktariani. (2017). The Application of RCRR (Read, Cover, Remember, Retell) Strategy in Teaching Reading Descriptive Text to the Eight Grade Students of State Junior High School 50 Palembang.

Fraenkel, J. R., Wallen, N. E., \& Hyun, H. H. (2012). How to Design and Evaluate Research in Education (8th ed.). New York: McGraw Hill.

Foertsctr, M. (1998). A study of Reading Tractice, Instruction, and Achievement in District 3I Schools.Oak Brook, IL: North Centrdl Regional Education Laboratory. Retrieved from file:///d:/My\%20Documents/000001/agama/strategy.aspx\%20.htm

Gerald G. D. (2009). Explaining Reading. New York: The Guilford Press.

Grabe, W. (2009). Reading in a Second Language: Moving from Theory to Practice. New York: Cambridge. University Press.

Hake, R. R. (1999). Analyzing change/gain scores. [Online]. Available at: http://www.physics.indiana.edu/ sdi/AnalyzingChange-Gain.pdf [June 20th, 2017]

Karimi, L., \& Veisi, F. (2016), The impact of teaching critical thinking skills on reading comprehension of Iranian intermediate EFL learners. Theory and Practice in Language Studies, 6(9), 1869-1876.

Katemba, C., V. (2019), Students' Vocabulary Enhancement at Grade 10: A Comparative Study Using CALL \& MALL in Indonesia. CALL-EJ, 20(1), 87-114. http://callej.org/journal/20-1/Katemba2019.pdf

Klingner, K. J., Vaughn, S., \& Boardman, A. (2007). Teaching Understanding Reading to Students with Learning Difficulties. New York: The Guilford Press

Lacina, J., Baulm, M., \& Taylor, E. R. (2016), Promoting Resilience through read-alouds YC Children, Institute of Educaton Sciences, 71(2), 16-27.

Masriyah. (1999). Validitas dan Realibilitas. Surabaya : Unesa University Press

Morrisson, N., (2014), How School are Breaking Down the Language Barrier for EAL Students. The Guardian International Edition.

National Research Council (2004). Engaging Schools: Fostering High School Students' Motivation to Learn, (Washington DC: The National Academies Press, 2004), 62. Retrieved from: http://etheses.iainkediri.ac.id/375/3/bab2\%20fix.pdf 
Pang, S. et al. (2003). Teaching Reading. Brussels: International Academy of Education (IAE).

Permendiknas no.23 Tahun 2006: Standar Kompetensi Lulusan Untuk Satuan Pendidikan Dasar dan Menengah. Jakarta: Depdikbud.

Ratumanan, T. G. (2003). Evaluasi Hasil Belajar yang relevan dengan kurikulum berbasis kompetensi. Surabaya: Unesa University Press

Ruseffendi, E. T. (1998). Statistika dasar untuk penelitian pendidikan. Bandung: IKIP Bandung Press.

Sam, D. P., \& Premalatha, R. (2013). Using Graphic Organizers to Improve Reading Comprehension Skills for the Middle School ESL Students. The journal English Language Teaching 8(2)155-170

Scott, G. P., \& Steven, A. S. (2005). Children's Reading Comprehension and Assessment London: Lawrence Erlbaum Associates. 2015, Publishers, pp 134.

Shanahan, T. (2006). The National Reading Panel Report: Practical Advice for Teachers. Chicago: Learning Point Associates.

Snow, C. (2002). Reading for understanding: Towards a R\&D program in reading

Spears, D. (2013). Improving Reading Skills. Seventh Edition. San Francisco: McGraw Hill Companies Inc. Strategies at Senior High School. STKIP PGRI Sumatera Barat.

Suherman, E. (2003). Evaluasi Pembelajaran Matematika. Bandung: JICA UPI.

The Jakarta Post. (2016). Indonesia Ranks Second-Last in Reading Interest. Retrieved from: https://www.thejakartapost.com/life/2016/08/29/indonesia-ranks-second-last-inreading-interest-study.html

The Jakarta Post. (2013). PISA 2013: Lessons for Indonesia. Retrieved from: https://www.thejakartapost.com/news/2013/12/06/pisa-2013-lessons-indonesia.html

Yulimariza, N. (2013). Teaching Reading Comprehension by Combining Read, Cover, Remember, Retell and Three Two One Strategies at Senior High School. Journal of English Education.Vol.2, No.2. p 5-6. 